\title{
The Influence of Future Cash Flow Predictions on Profits in Companies Listed on the Indonesia Stock Exchange
}

Titik Purwanti

Widya Dharma University Klaten, Indonesia Corresponding email: titik@unwidha.ac.id

\begin{abstract}
:
This research was conducted to determine the effect of future cash flow predictions on profits (gross profit, operating profit, and net income) in food and beverage companies listed on the Indonesia Stock Exchange. The method used in this research used purposive sampling with a population of food and beverage companies listed on the Indonesia Stock Exchange for the period 2016-2018. The samples in this research were 19 companies. The results obtained indicate that the operating profit variable has a partial effect on future cash flows, while the net income variable and the gross profit variable do not partially affect future cash flows. Simultaneously, gross profit, operating profit and net income have an effect on future cash flows.
\end{abstract}

\section{Keywords:}

cash flow, profit, food and beverage companies, IDX

JEL: O10, 014

\section{INTRODUCTION}

Cash flow is a financial report that contains the influence of cash and operating activities, investment transaction activities and financing transaction activities as well as net increase or decrease in a company for a period (Setiawati, 2018). Cash inflows are reports of cash receipts originating from routine company activities, for example sales of company assets, cash sales. Cash outflows are reports of continuous expenses, such as dividends, tax payments and interest payments. Cash flow takes place continuously as long as the company carries out its activities.

Since the issuance of PSAK No. 2 of 1994 which was established starting January 1, 1995, cash flow statements have become an integral part of the financial statements and have become an obligation for companies to prepare cash flow statements and provide cash flow information of cash equivalents (Hans Kartikahadi 1994: 24). Prediction of future cash flows. can be achieved if investors have information relating to the company. To get the maximum profit and the certainty of the profit results, it is necessary to first evaluate the company's performance. Users of financial statements are expected to be able to predict the company's performance to get profit (cash and cash equivalents) well if they get accurate information on the financial position and changes in the company's financial position and cash flow statements (Shofiahilmy Rispayanto, 2019: 2).

Noor Shodiq Askandar's research (2019) shows that gross profit and net profit have a significant effect, while operating profit has a negative effect in predicting future cash flows. Meanwhile, Helda Yulia Siska's research (2016) shows that operating cash flow and operating profit have a positive effect in predicting future cash flows, while operating working 
capital has a negative effect in predicting future cash flows. Research by Nining Mulyaningsih and Dwi Rahayu (2016) shows that there is a significant positive effect between net income and operating cash flow on dividend policy.

From the explanation above, the researcher is interested in conducting research with the theme "The Influence of Future Cash Flow Predictions on Profits in Companies Listed on the Indonesia Stock Exchange". By using the financial report data of the food and beverage industry go public during 2016-2018.

\section{LITERATURE REVIEW Cash Flows}

Cash flow is a financial report that contains the influence of cash and operating activities, investment transaction activities and financing transaction activities as well as net increase or decrease in a company during a period (Setiawati, 2018). Cash inflows are reports of cash receipts that come from routine company activities, for example sales of company assets, cash sales. Cash out flows are reports of expenditures that are continuous in nature, such as dividends, tax payments and interest payments. Cash flow takes place continuously as long as the company carries out its activities. The cash flow statement is classified according to three activities, namely, operating activities, investing activities, and financing activities. (Samryn, 2015) Meanwhile, according to Nelson Lam, Peter Lau (2015) in the cash flow statement, cash receipts and payments are classified according to three main categories, namely:

a. Operating activities, operating activities that come from cash flows include: cash payments to goods and services agents, cash receipts from the sale of goods and services, cash obtained from commissions, royalties and other income, cash payments for the benefit of employees.

b. Investing activities, investing activities include: cash payments to acquire fixed assets, cash receipts from sales of intangible assets and long-term assets, cash payments to recognize the capital and debt instruments of other entities, cash receipts from sales of capital or debt instruments from entities other.

c. Funding activities, among others: cash obtained from issuance of shares, cash obtained from issuing bonds, loans, debt and other short and long term loans, repayment of cash loans that have been issued.

\section{Gross Profit}

Gross Profit is a measure of a company's direct income on sales of its products during an accounting period. Gross profit equals net sales less cost of goods sold (July, 2019). According to Muhamad Ardi (2018) Gross profit is the difference between net sales and the cost of goods sold. Credit sales prove that there is an opportunity for incoming cash to be received from customers to predict the company in the future. This proves that the value contained in gross profit often allows for an influence in predicting future operating cash flows. It can be shown that the gross profit figure is a provision of information that can be used in predicting future operating cash flows as well as meeting the information needs for users of financial statements to make decisions.

\section{Operational Profit}

Operating Profit, according to Ainiyah, is all income and expenses as well as profits and losses that come from transactions related to activities, especially and outside of sales (Ainiyah, 2018). Menurur Nina Herlina (2019) Operating profit is realized income that arises during a one year period with related costs. So that operating profit is the differcnse 'jetween 
gross profit and operating expenses. The results of operating profit can be calculated from income minus expenses related to company operations, such as salary expenses, advertising expenses, depreciation, administrative expenses and others. These expenses are not fully related to the company's operating profit and are also still influenced by company policy. Where the company's operating expenses increase, the company's operating profit has decreased. Thus, the payment for company operating expenses increases and results in a decrease in cash originating from the company's operating activities. Profitable operating activities will result in cash receipts exceeding the amount invested and consequently will increase cash inflows.

\section{Net Profit}

Net income is the value of profit or excess income from trading activities in a certain period, where the value has been reduced by income tax expense. Net profit (Net Profit) is the profit that has been deducted by costs which are the company's expenses in a certain period including taxes (Kasmir, 2016). According to Wowor (2014) Net income is the excess of all income over all expenses for a certain year after deducting income tax which is presented in the form of an income statement. The improvement between net income and operating cash flow can make it easier for financial statement users to predict future cash flows, through prediction of profit. Thus, it can be indicated that the net income figure can help users of financial statements to predict future operating cash flows.

\section{RESEARCH METHOD}

This research uses secondary data, the data used in this study are financial statements of food and beverage companies listed on the Indonesia Stock Exchange (IDX) which include income statements and cash flow reports related to the object of research. The data is quantitative, because it uses numbers that show the value of the variables for which there are sources of research data that are differentiated into 2 , namely secondary data sources and primary data sources (Sugiyono). The populations in this research were food and beverage companies listed on the Indonesian stock exchange during 2016-2018. The sampling technique used in this research is non-probability sampling with the technique taken, namely purposive sampling. The criteria for research are food and beverage companies listed on the Indonesian stock exchange in 2016-2018, these companies publish financial reports consistently, and are able to prove the condition of profits during 20162018.

\section{RESULT AND DISCUSSION \\ Descriptive Statistics Analysis}

Descriptive Statistics Test Results

\begin{tabular}{|l|r|r|r|r|r|}
\hline & N & Minimum & Maximum & Mean & Std.Deviation \\
\hline X1 & 57 & 9,47 & 13,77 & 11,8223 & 0,97514 \\
X2 & 57 & 8,57 & 13,72 & 11,4241 & 0,92911 \\
X3 & 57 & 6,29 & 13,70 & 11,6100 & 1,21160 \\
Y & 57 & 8,96 & 13,32 & 11,1011 & 1,19636 \\
Valid N (listwise) & 57 & & & & \\
\hline
\end{tabular}

Source: Secondary data processed, 2020

1) Operating Profit $\left(X_{1}\right)$ 
The operating profit variable has the lowest value of 9.47 , the highest value of 13.77 , the average value of 11.8223 and the level of data distribution of 0.97514 .

2) Net Profit (X2)

The net income variable has the lowest value of 8.57 , the highest value of 13.72 , the average value of 11.4241 and the level of data distribution of 0.92911 .

3) Gross Profit $\left(X_{3}\right)$

The gross profit variable has the lowest value of 6.29 , the highest value of 13.70 , the average value of 11.6100 and the level of data distribution of 1.21160 .

4) Cash Flow (Y)

The cash flow variable $(Y)$ has the lowest value of 8.96 , the highest value is 13.32 , the average value is 11.101 and the level of data distribution is 11.19636

\section{The Result of Classical Assumption Test}

Normality Test

Table 2. Normality Test Results

One-Sample Kolmogorov-Smirnov Test

\begin{tabular}{|ll|r|}
\hline & & \multicolumn{1}{|c|}{ Unstandardized Residual } \\
\hline Normal Parameters & Mean & 57 \\
& Std. Deviation & 0,0000000 \\
Most Extreme & Absolute & 0,72029468 \\
Differences & Positive & 0,090 \\
& Negative & 0,068 \\
Test Statistic & & $-0,090$ \\
Asymp. Sig. (2-tailed) & & 0,090 \\
& & $0,200^{\mathrm{c}, \mathrm{d}}$ \\
\hline
\end{tabular}

Source: secondary data processed, 2020

The normality test shows that the Kolmogorov Smirnov test results prove that the significance value (Asymp. Sig 2-tailed) is greater than 0.05 , namely $0.200>0.05$, it can be concluded that the residual data is normally distributed.

Multicollinearity Test

Table 3. Multicollinearity Test Results

Coefficientsa

\begin{tabular}{|c|c|c|c|}
\hline \multicolumn{2}{|c|}{ Model } & \multicolumn{2}{|c|}{ Collinearity Statistics } \\
\hline \multirow{4}{*}{1} & \multirow{3}{*}{$\begin{array}{l}\text { (Constant) } \\
\mathrm{X} 1 \\
\mathrm{X} 2\end{array}$} & Tolerance & VIF \\
\hline & & 0,248 & 4,035 \\
\hline & & 0,354 & 2,828 \\
\hline & X3 & 0,461 & 2,167 \\
\hline
\end{tabular}

a. Dependent Variable: $Y$

Source: Secondary data processed, 2020

The multicollinearity test in table 3 above shows that operating profit, net income and gross profit have a VIF value and a tolerance value where the VIF value must be greater than 0.10 and the teleranca value must be below 10 , the following can be explained below. this:

a) Operating profit (X1)

In the operating profit variable (X1), the result is a tolerance value of $0.248>0.10$ and VIF of $4.035<10$, which means that there is no multicollinearity.

b) Net income (X2) 
In the net income variable (X2), the tolerance value is $0.354>0.10$ and VIF is $2.828<10$, meaning that there is no multicollinearity.

c) Gross Profit (X3)

For the gross profit variable (X3), the tolerance value is $0.461>0.10$ and VIF $2.167<10$ means that there is no multicollinearity.

Autocorrelation Test

Table 4. Autocorrelation Test Results Model Summary ${ }^{b}$

\begin{tabular}{|l|c|c|r|r|r|}
\hline Model & $\mathrm{R}$ & $\begin{array}{c}\mathrm{R} \\
\text { Square }\end{array}$ & Adjusted R Square & Std. Error of the Estimate & Durbin-Watson \\
\hline 1 & $0,798^{\mathrm{a}}$ & 0,638 & 0,617 & 0,74040 & 2,056 \\
\hline
\end{tabular}

a. Predictors: (Constant), X3, X2, X1

b. Dependent Variable: $Y$

Source: Secondary data processed, 2020

The results of the autocorrelation test where the Durbin Watson number generated from the data regression model is 2.056, while from the DW table with a significance of 0.05 and the amount of data $(n)=57$, and $k=3$ ( $k$ is the number of independent variables) the dL value is obtained 1.4637 and $\mathrm{dU}$ of 1.6845 . Because the DW value (2.056) is in the $\mathrm{dU}<\mathrm{d}<4$-dU area $(1.6845<2.056<2.3155)$, Ho is accepted, which means there is no autocorrelation.

Heteroscedasticity Test

Table 5.Heteroscedasticity Test Results

Coefficients $^{a}$

\begin{tabular}{|c|c|c|c|c|c|c|}
\hline \multirow{2}{*}{\multicolumn{2}{|c|}{ Model }} & \multicolumn{2}{|c|}{$\begin{array}{c}\text { Unstandardized } \\
\text { Coefficients }\end{array}$} & \multirow{2}{*}{$\begin{array}{c}\text { Standardized } \\
\text { Coefficients } \\
\text { Beta }\end{array}$} & \multirow[b]{2}{*}{$\mathrm{t}$} & \multirow[b]{2}{*}{ Sig. } \\
\hline & & $B$ & Std. Error & & & \\
\hline \multirow[t]{4}{*}{1} & (Constant) & 1.840 & 0,785 & & 2.344 & 0,023 \\
\hline & $X 1$ & $-0,117$ & 0,125 & $-0,249$ & $-0,938$ & 0,353 \\
\hline & $\mathrm{X} 2$ & $-0,072$ & 0,110 & $-0,145$ & $-0,654$ & 0,516 \\
\hline & X3 & 0,079 & 0,074 & 0,209 & 1,071 & 0,289 \\
\hline
\end{tabular}

a. Dependent Variable Cash Flows

Source: Secondary data processed, 2020

The Heteroscedasticity test results in table 5 above prove the following:

a) Operating Profit (X1)

In the operating profit variable $(X 1)$ a significance value of $0.353>0.05$ means that there are no symptoms of heteroskesasticity.

b) Net Profit (X2)

In the Net Income variable (X2), the significance value is $0.516>0.05$, which means that there are no symptoms of heteroskesasticity.

c) Gross Profit (X3)

In the gross profit variable $(X 3)$, the significance value is $0.289>0.05$, which means that there are no symptoms of heteroskesasticity.

\section{Hypothesis Testing Results}

Multiple Regression Analysis

Table 6.Cash Flow Regression Test Results Coefficients $^{a}$ 


\begin{tabular}{|c|c|c|c|c|c|c|c|c|}
\hline \multirow{2}{*}{\multicolumn{2}{|c|}{ Model }} & \multicolumn{2}{|c|}{$\begin{array}{l}\text { Unstandardized } \\
\text { Coefficients }\end{array}$} & \multirow{2}{*}{$\begin{array}{c}\text { Standardize } \\
\mathrm{d} \\
\text { Coefficients } \\
\text { Beta } \\
\end{array}$} & \multirow[b]{2}{*}{$\mathrm{t}$} & \multirow[b]{2}{*}{ Sig. } & \multicolumn{2}{|c|}{$\begin{array}{l}\text { Collinearity } \\
\text { Statistics }\end{array}$} \\
\hline & & B & $\begin{array}{l}\text { Std. } \\
\text { Error }\end{array}$ & & & & Tolerance & VIF \\
\hline \multirow[t]{4}{*}{1} & (Constant) & 1,957 & 0,280 & & 0,748 & 0,458 & & \\
\hline & $\mathrm{X} 1$ & 0,699 & 0,204 & 0,570 & 3,431 & 0,001 & 0,248 & 4.035 \\
\hline & $\mathrm{X} 2$ & 0,226 & 0,179 & 0,176 & 1,264 & 0,212 & 0,354 & 2.828 \\
\hline & X3 & 0,104 & 0,120 & 0,105 & 0,864 & 0,392 & 0,461 & 2.167 \\
\hline
\end{tabular}

Dependent Variable: $Y$

Source: Secondary data processed, 2020

The multiple linear regression equation is as follows: $Y=1.957+0.699 \mathrm{X} 1+0.226 \mathrm{X} 2+$ $0.104 \times 3$

a) Constant (a)

If the constant (a) of all independent variables has a value of zero $(0)$, the value of the dependent variable (Beta) is 1.957.

b) Operating Profit $\left(\mathrm{X}_{1}\right)$ against beta $(\mathrm{Y})$

The operating profit coefficient value for variable $X 1$ is 0.699 . This means that for each one unit increase in operating profit, the Beta $(Y)$ variable will increase by 0.699 with the assumption that the other independent variables of the regression model are fixed.

c) Net Income $\left(\mathrm{X}_{2}\right)$ against beta $(\mathrm{Y})$

The net profit coefficient value for variable $X_{2}$ is 0.226 . This means that every one unit increase in net income, the Beta $(Y)$ variable will increase by 0.226 with the assumption that the other independent variables from the regression model are fixed.

d) Gross Profit $\left(X_{3}\right)$ against beta $(Y)$

The value of the gross profit coefficient for variable $X_{3}$ is 0.104 . This implies that every one unit increase, the Beta $(Y)$ variable will increase by 0.104 with the assumption that the other independent variables of the regression model are fixed.

Partial Test

a) Operating Profit $\left(\mathrm{X}_{1}\right)$ against Beta $(\mathrm{Y})$

In the net profit variable, the results of tcount $(3,431)>t_{\text {table }}(2.005)$ with a significance of $0.001<0.05$ means that $\mathrm{Ho}$ is rejected and $\mathrm{Ha}$ is accepted so that it can be concluded that operating profit partially has a partial effect on future cash flows at food companies and drinks listed on the Indonesian Stock Exchange (IDX) in 2016 - 2018.

b) Net Income $\left(\mathrm{X}_{2}\right)$ to Beta $(\mathrm{Y})$

In the net income variable, the results of the value of tcount $(1.264)<t$ table (2.005) with a significance of $0.212>0.05$ means that $\mathrm{Ho}$ is accepted and $\mathrm{Ha}$ is rejected so that it can be concluded that net profit does not have a partial effect on future cash flows at food companies and drinks listed on the Indonesian Stock Exchange (IDX) in 2016 - 2018.

c) Gross Profit $\left(X_{3}\right)$ against Beta $(Y)$

In the gross profit variable, the result of tcount $(0.864)<t$ table $(2.005)$ with a significance of $0.392>0.05$ means that $\mathrm{Ho}$ is accepted and $\mathrm{Ha}$ is rejected, so it can be concluded that gross profit partially does not have a partial effect on future cash flows at food companies. and beverages listed on the Indonesia Stock Exchange (IDX) in 2016 - 2018.

Simultaneous Test

Table 7.F Test Results (Simultaneous) ANOVA $^{a}$

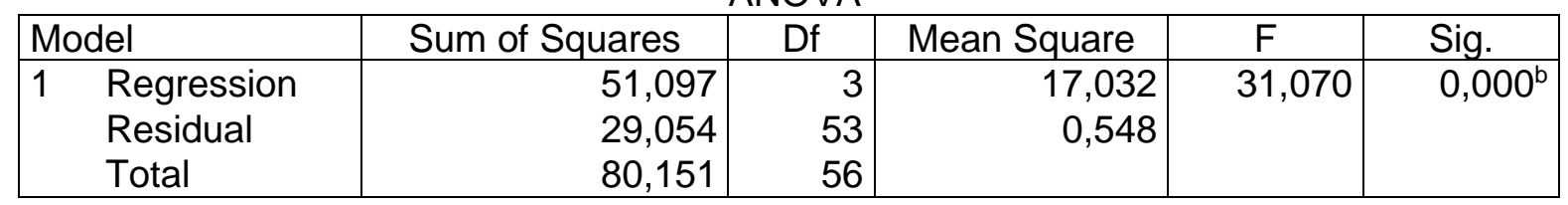


a. Dependent Variable: $Y$

b. Predictors: (Constant), X3, X2, X1

Source: Secondary data processed, 2020

Based on the results of the $F$ test (simultaneous) in table 7, the value of Fcount $31.070>$ Ftable 2.78 with a significance of $0.000<0.05$, it can be concluded that Ho is rejected and $\mathrm{Ha}$ is accepted. Simultaneously it can be concluded that the operating profit variables $\left(\mathrm{X}_{1}\right)$, net income $\left(X_{2}\right)$, gross profit $\left(X_{3}\right)$ have a simultaneous influence on future cash flows in food and beverage companies listed on the Indonesian stock exchange (BEI) in 2016- 2018.

Determination Coefficient Test

Table 8: Test results of the coefficient of determination $\left(R^{2}\right)$ Model Summary

\begin{tabular}{|l|r|r|r|r|}
\hline Model & $\mathrm{R}$ & $\mathrm{R}$ Square & Adjusted R Square & Std. Error of the Estimate \\
\hline 1 & $0,798^{\mathrm{a}}$ & 0,638 & 0,617 & 0,74040 \\
\hline
\end{tabular}

a. Predictors:(Constant), X3, X2, X1

b. Dependent Variable: $Y$

Source: Secondary data processed, 2020

The coefficient of determination test results is carried out to determine how much the dependent variable can be explained by the independent variable. The coefficient of determination test results show the Adjusted $\mathrm{R}$ Square number of 0.617 or $61.7 \%$. This means that the contribution of net income, operating profit and gross profit to cash flow is $61.7 \%$ and the remaining $38.3 \%$ is influenced by other variables.

\section{CONCLUSION}

Based on the description above, it can be concluded that this study shows that the operating profit variable has a partial effect on future cash flows, while the net profit and gross profit variables do not have a partial effect on future cash flows. Simultaneously, gross profit, operating profit and net income have an effect on future cash flows.

\section{REFERENCES}

Ainiyah, N. (2018). Pengaruh Laba Kotor, Laba Operasi Dan Laba Bersih Untuk Memprediksi Arus Kas Masa Depan Pada Perusahaan Food \& Beverages Yang Terdaftar Di Bei Periode 2015-2017. Skripsi. Jawa Timur: Fakultas Ekonomi,Universitas Islam Majapahit.

Ardi, M. (2018). Analisis Laba Kotor Sebagai Alat Untuk Mementukan Naik Turunya Harga Jual Pada Qmart Superstore Kota Goronontalo. Jurnal Al Buhuts. Vol. 1, No 1: Hal 124 $-146$.

Ariani, M. Dwi. (2010). Pengaruh Laba Kotor, Laba Operasi Dan Laba Bersih Dalam Memprediksi Arus Kas Di Masa Mendatang. Skripsi. Semarang Fakultas Ekonomi, Universitas Diponegoro.

Askandar, N S. (2019). Pengaruh Laba Kotor,Laba Operasi Dan Laba Bersih Dalam Memprediksi Arus Kas Di Masa Mendatang. (Studi Empiris Perusahaan Manufaktur Di Bursa Efek Indonesia tahun 2012-2017). Jurnal Ilmiah Riset Akuntansi. Vol.8, No 1: Hal. $53-64$.

Dwi R \& Nining M. (2016) Pengaruh Laba Bersih Dan Arus Kas Operasi Terhadap Kebijakan Dividen Pada Perusahaan Food And Beverage Yang Terdaftar Di Bursa Efek Indonesia 2010 - 2014. Jurnal Ekonomi. No. 43.Hal. 33-43.

Herlina, N. (2019). Peningkatan Laba Oporasi Dengan Pengendalian Biaya Produksi. Sustainable Competitive Advantage. Vol 9, N0 1. Hal. 207-221.

Ikatan Akuntansi Indonesia. PSAK No. 2. (2015) Tentang Laporan Arus Kas. Jakarta: Dewan Standar Akuntansi. 
Jordan S S. (2015). Pengaruh Laba Kotor, Laba Operasi, Laba Bersih Dalam Memprediksi Arus Kas Masa Mendatang. Skripsi. Jember: Universitas Jember.

Kasmir. (2016). Analisis Laporan Keuangan.Jakarta: PT Raja Grafindo Persada.

Lau, Peter.,Lam,Nelson. (2015). Intermediate Financial Reporting.An:IFRS Perspective. Jakarta: Selemba Empat.

M, Mamduh. (2016). Analisis Laporan Keuangan Edisi Kelima. Yokyakarta: UPP STIM YKPN.

Mawikere, M Lidia dan Ventje llat. (2017). Pengaruh Laba Bersih, Perubahan Piutang Usaha, Perubahan Utang Usaha Dan Perubahan Persediaan Terhadap Arus Kas Operasi Di Masa Depan Pada Perusahaan Yang Terdaftar Dalam Indeks Lq45 Di Bursa Efek Indonesia Tahun 2011-2015. Jurnal Imba. Vol.5, No.2: Hal. 1484-1492.

Putri, Ayu dan Ayu Yuli. (2019). Analisis Pengaruh Komponen Arus Kas Dan Laba Kotor Terhadap Harga Saham ( Studi Empiris Pada Perusahaan Farmasi Yang Terdaftar Di Bursa Efek Indonesia Tahun 2012-2016). Jurnal Of Multidisciplinary Research And Development.Vol.1: No 3: Hal. 436-448.

Rispayanto, S. (2013) Pengaruh Laba Kotor, Laba Operasi, Laba Bersih Dalam Memprediksi Arus Kas Masa Mendatang. Jurnal akuntansi. Vol.1: No.3: Hal: 1- 13.

Samryn. (2015). Pengantar akuntansi buku dua.jakarta: PT Raja Grafindo persada.

Setiawati, D. (2018). Pengaruh Laba Bersih dan Arus Kas Operasi Terhadap Harga Saham Pada Perusahaan Food and beverages Yang Terdaftar Di Bursa Efek Indonesia Periode 2012-2015. Jurnal Ekonomi Dan Bisnis vol.11, No 2: 319-330.

Siska, H Y. (2016). Kemampuan Laba Operasi, Arus Kas Operasi Dan Modal Kerja Dalam Memprediksi Arus Kas Masa Depan pada perusahaan manufaktur yang terdaptar di bursa efek Indonesia pada tahun 2010-2014.Skripsi.Surabaya: STIE Perbanas Surabaya.

Subramanyam. (2010). Analisis Laporan Keuangan. Jakarta: Salemba Empat.

Sugiyono. (2017). Metode Penelitian Pendidikan Pendekatan Kuantitatif, Kualitatif Dan R\&D. Bandung: Alfabeta.

Sutedji, A. (2018). Pengaruh Laba Kotor, Laba Operasi, Laba Bersih Dalam Memprediksi Arus Kas Di Masa Mendatang Pada Perusahaan Makanan Dan Minuman Yang Terdaftar Di Bursa Efek Indonesia tahun 2014-2017. Skripsi. Jakarta: Universitas Satya Negara Indonesia. 